\title{
Population-related Policies in Estonia in the 20th Century: Stages and Turning Points
}

\author{
KALEV KATUS, Ph.D., Professor and Director \\ ALLAN PUUR, Ph.D., Senior Researcher \\ ASTA PÕLDMA, M.A., Researcher \\ Estonian Interuniversity Population Research Centre, Tallinn, Estonia
}

\begin{abstract}
This article is about the experience of population-related policies in Estonia. During the recent decade much has been published on this theme, usually with an analysis of currently enforced regulations. Repeated amendments of legal norms and procedures, which are inevitable in a period of fundamental reforms, however, tend to limit their value quite rapidly. Against such a background, this paper applies a longer perspective with an attempt to cover the main stages and turning points in the development of population-related policies in the country since the establishment of statehood in 1918.
\end{abstract}

In the interwar period, the efforts to build up a modern nation included setting up relevant institutions and regulations in the field of population-related policies. These undertakings have been seldom discussed in the recent publications. Somewhat similarly, the postwar decades are frequently regarded as fairly distant and of little relevance to present challenges. To understand the developments, however, the longer view should not be neglected. Today's concerns are rooted in the arrangements and disarrangements of the past, and no less importantly, such continuity is strengthened by the nature of population development and the flow of cohorts which absorb the influences of the societal environment and carry them along through their lifetime.

The article is structured in four sections focusing on the development of marriage and the family, children and fertility, the pension system and social welfare, and the health care system. In each section, the aim is to outline successive policy regimes and their main characteristics in terms of objectives and methods of regulations. Understandably, limited space does not allow coverage of minor changes and technicalities, so for more specific information the article provides further reference to various source materials.

Keywords: Estonia, ageing, family, fertility, population-related policies, population, public health, social policies.

The article has been prepared in the framework of research theme 0501463s00 and supported by the ETF grant No. 5982. 


\section{Marriage and the Family}

In this section, the eight and a half decades of the Republic of Estonia have been divided into four major stages, defined by the interplay of societal context and regulations, and transformations in population development. The following subsections outline the timeframe and characteristic features of those stages.

Institution of civil marriage

The first period with respect to marriage and the family covers the two decades until 1940. The demographic, economic and social development in Estonia had followed the general tide of modernization since the middle of the 19th century. The First World War enabled Estonia, together with Finland, Latvia, Lithuania and Poland at the Baltic Sea to gain independence, which also implied a final departure from a societal structure based on position (Laaman 1964). As elsewhere in Northern and Western Europe, this development included the institution of civil marriage, which occurred in two steps in Estonia. In 1920 registration offices were opened at city governments in Tallinn, Tartu, Narva and Valga, to provide an alternative for persons, who, for one reason or another, did not opt for ecclesiastical marriage.

The reform was completed in 1926 when the new Family Law transferred the legal recognition of marriage from the church to the state. Starting from July 1, 1926, the rights of an individual generated through marital and family relations became wholly dependent on civil registration (RT 1925, 191/192). More importantly, the regulations and procedures which had differed in relation to position and religious faith became identical for all citizens of the country. At the same time, continuity with the law for the Baltic provinces was maintained. From the modern viewpoint, the 1926 Family Law expressed several traditional views, which were characteristic of Western European legislation of that period. The norms stipulated the superiority of the husband in some aspects, marriage was regarded as a life-long commitment and divorce was based largely on the culpability of spouses, systematic distinction was made between the position of children born in or outside of wedlock etc.

An important innovation brought by the 1926 Family Law was the introduction of modern civil registration in Estonia. The reform called into being the Civil Registration Office (Perekonnaseisuamet) and standardized the procedures, including the system of recording, forms, language, liaison with the statistical office etc., the responsibility for local registration was placed on the municipalities (Teder 1939). From the onset, a strong emphasis was put on quality and accuracy, and the civil registration office was delegated a relatively broad range of responsibilities in the contemporary context. A population register was introduced which kept a cumulative individualized account of events pertaining to each member of the resident population. The aim was to have coverage of the entire population with register records by 
1939-1940. The office played a central role in arranging personal names, including the Estonianization of family names, in the course of which almost one fifth of the population chose a new surname (Must 2000).

In a broader framework, a major contribution to the welfare of the population and families was made by societal reforms undertaken in the early years of the Estonian Republic. Among those, the land reform promulgated by the Estonian Parliament in October 1919 is of key importance. In the course of reform, manorial estate lands were expropriated and distributed among farm operators (Kahk and Tarvel 1997). By comparing the outcome of Estonian land reform with similar undertakings carried out in other regions of Eastern and Central Europe and the Balkans, the share of medium-sized and large farms appeared to be more than twice as high in Estonia. Combined with the well-established tradition of agricultural cooperation, the reform consolidated the economic foundation of families among a broad stratum of the population.

\section{Family implications of societal discontinuity}

The Molotov-Ribbentrop Pact divided Central and Eastern Europe, and as a result, Estonia was annexed to the Soviet Union in June 1940. In 1941-1944, Estonia fell under German occupation, and in 1944 the second Soviet occupation began. The new regime introduced a systematic rearrangement of the entire societal organization which was particularly forceful and violent until the mid-1950s. This period of societal discontinuity merits separate attention for its distinct implications on families.

Following the annexation, Soviet law was brought into force. The enforcement of Soviet family regulations had little, if any direct bearing on the patterns of family formation and dissolution in the population statistics of the 1940s and 1950s. This conclusion does not mean, however, that families in Estonia were left untouched. On the contrary, the influence of societal discontinuity on the population can be regarded as very extensive although the gaps in the statistics do not allow for easy quantification. During the recent decade the piece by piece $^{1}$ assembling of missing information has been in progress, but no comprehensive generalization has yet been reached.

The impact of societal discontinuity on families can be estimated retrospectively from event history surveys. Most importantly, a sharp and anomalous drop in the proportion of the population brought up in intact two-parent family is revealed by the

1 Lists of victims of political arrests and mass deportations have been compiled (Salo 1993; Sabbo 1996; Õispuu 1996-2001). Population losses have also been examined for some counties (Kotkas 1999; Nurk 1999; Piir 1991-1997; Sissas 1990-2002) and professional groups, e.g. medical doctors (Merila-Lattik 2000). 
Estonian FFS. Among the native population, the percentage fell from a level close to 90 percent in the birth cohorts of the 1920 s to below 70 percent among those born in 1939-1943. In contrast to most European countries, the downsurge was not followed by a rapid recovery at the end of WWII, and instead it took until the late 1950s for the family structure to recover. The analysis attributes the disruption of the parental home directly to situations where either the respondent's mother or father was killed, sentenced to long-term imprisonment or deported (Katus, Puur and Põldma 2002). Across population groups, the upper and middle strata were particularly hard hit, for example, with the risk of parents with a university education being repressed exceeding 50 percent. The comparable disruptive effect of societal discontinuity caused by rising parental divorce rates has proven to be at least two times weaker. As an experience accumulated in the family of origin, the effects of the repressions have not been limited to childhood: their repercussions have been felt in subsequent life stages. Against that background, it should be noted that retrospective data account only partly for situations where entire families were repressed - for example, in the largest deportation in 1949 women and children constituted three fourths of the deportees (Rahi 1998).

Major changes occurred also in the field of civil registration which had developed into a relatively advanced system in the interwar period. The new authorities - under NKVD supervision - ordered the cancellation of the family register. The official decree to abolish the register was issued just weeks before the mass deportation in March 1949. The national statistical system underwent the same experience when it was dismantled and replaced by a subordinate branch, charged with the implementation of instructions from authorities outside the country (Katus and Puur 2003).

\section{Responses to the growing diversity of family forms}

In the mid-1950s, the cessation of political repressions marked a significant decrease in the intervention of state authorities into private life and brought relief to the population. In other words, external influences decreased in importance and relevant legislation assumed its regulatory role in the realm of marriage and the family. Although the general concept of family legislation was unchanged until the end of the 1980 s, some modifications in the regulation deserve attention.

In 1944, with the return of the Red Army to Estonia, severe restrictions were imposed on divorce, requiring a prolonged two-stage legal proceeding, payment of disproportionately high fees, and also, a mandatory announcement of divorce in a local newspaper. In fact, these measures suspended no-fault divorce and attempted to consolidate the life-long marriage characteristic of the traditional pattern of population reproduction. 
In the 1960s, family legislation was liberalized. In 1965, the previous restrictions on divorce were abolished and a less complicated legal procedure established. The change in proceedings resulted in a marked rise in the divorce rate the following year, reflecting the dissolution of marriages which had occurred but remained unregistered due to the strict procedure. After the upsurge of the divorce rate, however, the increasing trend continued over the next 15 years, stabilizing in the 1980s. In a comparative perspective, Estonia belongs to the group of countries which have featured the highest frequency of divorce in Europe (CoE 2003). Understandably, the rise in divorce has increased the prevalence of single-parent (mostly femaleheaded) families.

Regarding family formation, the traditional pattern - direct marriage where the start of partnership and formal registration closely coincide - began to decline and was gradually replaced by cohabitation. Although known earlier, a steady increase in the prevalence of cohabitation started in the 1960s (Katus, Puur and Põldma 2002). The trends were carried out by the birth cohorts of 1940s and later. In the birth cohorts of the 1950s cohabitation became the main route of family formation with more than half of first unions starting as cohabitation. Among the cohorts born in the second half of the 1960s, who started family formation in the last decade of state socialism, the proportion of direct marriage had dropped to below 20 percent, with further decline to follow. In comparative terms, the family formation among the native population in Estonia closely resembled the developments in the Nordic countries, and was quite different from Central and Eastern Europe, and the Soviet Union (Granström 1997; Nikander 1998; Noack and Ostby 1996).

At the same time, there were no corresponding amendments to the Marriage and Family Code (ÜPT 1969). In this way, the biggest transformation in the realm of the family concerned the area where the legal procedures remained unchanged. Perhaps the only provision which took into consideration the emerging change was the introduction of a joint declaration of the parents at the registration of the birth. The joint declaration provided an option (previously non-existent) for non-married parents to register their son/daughter as a common child, beyond the procedure of adoption. The Code ignored consensual unions as a type of family relationship separate from registered marriage, which was consistent with the stage of the population in most other parts of the USSR.

It has been hypothesized, however, that ignoring consensual unions still had an effect on the pattern of family formation - through housing policy (Katus, Puur and Põldma 2002). Under state socialism dwellings were distributed by the authorities based on certain criteria. With respect to couples, having a registered marriage was one of them. Moreover, since the birth of a child increased the number of family members per floor space, other things being equal, it also positively contributed to 
chances for qualifying for a new dwelling. Pragmatic considerations could explain the relatively early conversion of consensual unions into registered marriage and early entry into parenthood, compared to Northern and Western Europe. The same mechanism also contributed to very high divorce rates.

\section{Family regulations and behavior during the 1990s}

In the 1990s, statehood was reconstituted and the whole legal system renewed in Estonia ${ }^{2}$. In 1995, the new Family Law was enacted (RT 1994, no.75). In its basic concepts and scope of regulations, however, the new law bears a substantial resemblance to its predecessor, the 1969 Marriage and Family Code. First, only the traditional form of a family, a registered marriage, has been considered. Second, the family is regarded overwhelmingly as an economic unit. Among the few new elements, the 1995 law introduced a marital contract as a basis of property relations, supplementary to the statutory joint property regime. From the legal point of view, the contract offers protective mechanisms to cover situations where one of the spouses runs into economic hardship (Kullerkupp 2001). There are also some amendments. For example, the minimum age for marriage of minors was lowered from 16 to 15 years, under written consent of their parents.

As discussed in the previous section, the traditional pattern of family formation disappeared and was replaced with a new model already during the previous decades. A 1990s phenomenon was the sharp postponement of marriage. The mean age at first marriage increased by more than three years and the upward trend is still well in progress. On average, in 2002 males entered first marriage at the age of 28.2 years and females at the age of 25.5 years. As a result, the total first marriage rate fell to the level of 0.35, which is one of the lowest in Europe (CoE 2003). The timing of divorce has undergone less transformation. It should be noted that the change in the registration procedure of divorce - now immediately upon court decision and no longer upon the application by one of the spouses at some later stage - introduced the discontinuity in the time series. In particular, this resulted in the excess of the number of registered divorces over marriages in 1995.

In Northern and Western Europe, the two recent decades have signaled a new phase of family legislation with respect to unmarried (heterosexual) cohabitation (Bradley 2001). Against this background, the present Estonian law does not attach any explicit legal consequences to unions other than registered marriage. In these circumstances, cohabiting partners can apply private law in making appropriate legal arrangements to obtain common rights, inherit property etc. The concept of

2 All major Estonian legal acts are available at the following website: http: www.legaltext.ee. 
unmarried cohabitation is also applied in some laws regulating the economic and social domain ${ }^{3}$. Although the private law provisions allow for noticeable flexibility, the prevalence of cohabitation makes it reasonable to consider steps towards greater statutory regulation to safeguard the rights of individuals who have opted for cohabitation. Of course, the statutory regime for consensual unions can hardly be completely identical to that for registered marriages.

\section{Children and fertility}

Although policies aimed at fertility have been introduced mainly in the 20th century, with the exception of France, children have been, in one way or another, a subject of policy formulation for a long time. In modern society these two perspectives have merged together and it is easy to overlook the different origin of policies in this realm. Like other nations, Estonia has experienced a convergence of child-related and fertility-related policies. This has occurred along rather different paths, however.

In the following, the development of policies with respect to children and fertility in Estonia has been divided into five stages. The first stage represents the years of nation-building, following the War of Independence, with the effort to secure the living standards of children. The second stage outlines the societal response to the decline of fertility below replacement. The third stage covers the period of sovietization, and the fourth is characterized by a new interest towards fertility-related policies in the 1980s. The fifth stage addresses child- and fertility-related policies in the period of societal and economic transition.

\section{Integrated welfare policies for children}

Estonia inherited a mixture of regulations from the law systems of Russia and Germany, and particularly from the special Baltic order, granted by Peter I. Compared to Western and Northern European countries of the time, child-related policies corresponded to traditional society in the Russian Empire. On one hand, Estonia was affected by approximately half a century time difference in demographic development compared to the rest of the Empire, where the needs for child-related policies had not yet emerged. On the other hand, the ruling class in Estonia under the Russian Empire retained the Baltic order and tried to avoid all changes, regarded as undermining the stability of position-based society.

\footnotetext{
${ }^{3}$ Unmarried cohabitation is considered in bancruptcy law (RT 2001, no.93), in the law of credit institutions (RT 2002, no.23), the law of finacial inspectorate (RT 2001, no.48). Also, consensual unions are considered in the payment of income support benefits (Kama and Kulluerkupp 2002).
} 
Given the historical background and the hardship of the wars of 1914-1920, Estonia started to develop its child-related policies from scratch. The activities in the main spheres of child-related policies - improvement of social protection, health, education and the living conditions of children - proved comprehensive and far-sighted. It should be noted that new policies were closely coordinated across the various spheres. In modern wording, an integrated approach was applied to develop child welfare policies. Among others, the joint Ministry for Social Affairs and Education in the early 1920 s supported the idea of an integrated approach.

Children formed a target group of its own in the policies to secure a living standard and social cohesion. The primary responsibility for the living standard remained with the municipalities which operated the systems of continuous as well as occasional support. Also, the development of a network of institutions for children was started. In addition, a considerable number of services were provided by various voluntary organizations. The state supported the activities of municipalities and voluntary organizations on a regular basis, covering more than half of the costs from the budget. The principles of social protection of children were summarized in the Social Welfare Law (RT 1925, no. 120/121).

Education was given a very high priority in Estonia in the period of inter-war independence, with the main target group understandably being children. Already in 1917 Maanõukogu decided to switch to the Estonian language on the primary, secondary as well as the vocational and university levels. In 1920, a comprehensive reform integrated various types of schools into a unified national education system. A six-year primary school became compulsory and free of charge. To meet the demand for teachers, pedagogical teachers' colleges were opened at several locations, in addition to Tartu University. One indication of the substantial investment in education was the number of new schoolhouses built in the 1920s-1930s (Riigikantselei 1935).

The development of the national health care system foresaw special services for children. The country was covered by a network of consultation centers for mothers and children, under the coordination of the Department of Health. Services were provided by doctors and other medical personnel, free of charge for mothers and children up to seven years of age. In case of need, service was extended to home visits. The voluntary organization Eesti Lastekaitse (Estonian Child Welfare) was established, providing various services for children. The main principles of the national health service were summarized in the Public Health Promotion Law (RT 1928).

The needs of children were also considered in housing policy, aimed at securing housing standards, rent, sanitary norms etc. Reflecting the variation in housing conditions across the country, and the implementation of the measures was given to the 
municipalities. The population census of 1922 included a module on housing conditions which provided comprehensive data for policy-making (RSKB 1923-1925). The next census revealed that the progress achieved in housing conditions was quite impressive (RSKB 1934-1937).

Integrated welfare policies for children, in contrast to many European countries, were instituted over a relatively short period of time in Estonia in the 1920s. These efforts allowed the country to overcome the contradiction between the stage of population development and the state of social policies inherited from the Russian Empire. By the end of the 1930s, despite financial and time constraints, Estonia had reached advanced standards in the field.

\section{The onset of fertility-related policies}

The policies specifically aimed at influencing fertility - its levels, parity distribution, timing or other aspects of the process - is an invention of the 20th century. The response of society emerged as a reaction to very low levels of fertility which followed the long-term fertility decline during the demographic transition, experienced for the first time ever. The emergence of below-replacement fertility which indicates the universal spread of family planning across the entire population, called fertility-related policies into being in a number of European countries. Estonia reached under-replacement fertility in the middle of the 1920s, marking the beginning of a new era in fertility development (Katus 1997). During that period, however, there was very limited experience of fertility-related policies in Europe, and no relevant experience in the countries neighboring Estonia. To analyze the introduction of fertility-related policies - a principally new element of population policies - some contextual issues should be taken into account. Regarding Europe, one should recall the economic crises which probably postponed the societal response to demographic development. In Estonia, the political turbulence surrounding the enforcement of the new constitution and the change of regime (in 1934) could be assumed to have had a similar effect. On the other hand, the established statistical system provided an accurate and up-to-date account of the population, and informed about the emerging situation. For example, the data revealed that for the first time in normal conditions, depopulation had occurred ${ }^{4}$.

Low fertility formed the main agenda at the conference on national development (Eesti Rahvusliku Kasvatuse Kongress) in 1935. This conference brought together the viewpoints of major actors in society - experts, politicians, high-level administrators, representatives of the church and the fine arts. The president of the country

4 In 1929, negative population growth (-1068) was observed in Estonia. 
shared the concerns and stressed the need for a societal response. The conference adopted several resolutions which laid the basis for government policies in the field of fertility (Madisson 1935). Among the innovations were child allowances. The allowance was differentiated by the level of income, place of residence, and provided to each child up to 18 years of age and covered the families of central and local government employees, workers in state enterprises, and military personnel (RT 1935, no.87; 1936, no.93). Birth allowances were also introduced, and medical service related to childbirth was provided free of charge.

Following the recommendations of the conference, the Commission of Population and Welfare was instituted, charged with responsibility for the initiation and formulation of laws related to children and fertility. Also, upon the proposal of the Commission a chair of eugenics was established at Tartu University. The chair was given the task of monitoring major demographic processes (fertility, nuptiality and mortality), and analyzing the reasons for low fertility and population increase.

It is interesting to note that in the late 1930s fertility started to increase in Estonia. According to the available data, in 1942 period fertility reached its highest level in Estonia during the forty-year period of 1928-1968. The fertility increase in Estonia was, most probably, not so much the result of introduced policies, although they could have had a supportive effect. Recent analyses have shown that at the end of the 1930s an upward movement of fertility was characteristic of several European nations at a similar stage of demographic development (Calot et al 1998; Lundström 1999).

In Estonia the societal response to under-replacement fertility could be regarded as rather energetic, including a lively discussion as well as policy formulation. Most importantly, the new demographic situation and related needs became the subject of public debate, involving a large number of government institutions, civil society organizations and people. By and large, the views of government and people coincided, and the population issues became a factor consolidating the nation.

\section{Abolition of fertility-related policies}

Population policies, including fertility-related policies, lose significance in periods of war and crisis. In Estonia, this outcome was strengthened by three successive occupations, lasting almost fifty years. As can be expected, together with Estonian statehood the geopolitical change wiped out child- and fertility-related policies developed in the 1920s-1930s. From 1940 until Stalin's death, war and repressions outweighed any policy influence on children and fertility in Estonia, as already discussed in the previous section. 
As regards social policies, the regulations of the Soviet Union were enforced, based on a unified model. In the field of children and fertility, two sets of measures should be discussed. First, induced abortion became strictly prohibited in Estonia. proceeding from the concept of a large family, in 1944 special awards were instituted for mothers with a large number of children. Women with 10 or more children were awarded the order of Heroine Mother, mothers of 7-9 children and mothers with 5-6 children were awarded respectively the order of Mother's Glory and medals (ÜPT 1945, no.4). The ban on abortion was lifted in 1955, a few years after Stalin's death. However, the orders and medals awarded to mothers survived until 1991. Also, limited financial support was introduced for large families, families with low incomes and single mothers, but there were no fertility-related policies up to 1982 .

Against the background of a low profile for child- and fertility-related policies during almost four decades, it is interesting to examine the fertility trend in Estonia for the same period. Among the countries with comparable timing of demographic development, Estonia (as well as Latvia, but to a lesser extent) was the only country which did not experience the postwar baby boom. It is important to note that most, if not all other characteristics of the baby boom - among others, the increase in marriage, rejuvenation of marriage and fertility, decrease in childlessness etc. - were manifested in Estonia, except for the increase in fertility (Katus 2003). In Estonia, fertility remained below replacement, being the lowest in the world in the 1950s.

At the end of the 1960s, however, - parallel with the increase in the divorce rate, the spread of cohabitation and childbearing out of wedlock, rising levels of female education and workforce participation - fertility increased noticeably without introducing any new policy measures. Over a relatively short period of three to four years, period fertility increased by nearly one fifth, and after being under replacement for forty years, fertility returned close to replacement level and stayed there until the end of the 1980s.

During the period under discussion a major shift in population took place, which has long-term implications and needs to be considered also in the future. Large-scale immigration and the formation of a foreign-origin population introduced a duality of fertility patterns in Estonia. In the realm of family formation, fertility, abortion and other reproduction-related processes, two major subpopulations - native and foreign-origin - did differ not only with respect to the levels but also in terms of the direction of their trends. From the analytical point of view both subpopulations should be treated separately as the patterns for the total population represent a mechanical average of two rather different behaviors (UNECE 2000). 


\section{A new turn in fertility-related policies}

The short period 1982-1988 is singled out from the postwar decades because of a principal change in child- and fertility-related policies in the Soviet Union, including Estonia. In the 1970s, the Russian Federation and other core republics entered the stage of below-replacement fertility. Step by step, the interest in population development per se, i.e. as a separate domain of social policies, began to emerge. The outcome was a new approach in the Soviet context which was enforced in 1982 (ÜPT 1981, no. 22). In addition to the improvement of the welfare of children and families (a traditional component in Soviet policy) a fertility increase was emphasized as a distinct goal. Among others, the new regulation shifted the focus from large to average families.

According to the new regulations, child care leave was extended to 18 months, the first twelve months of which were on partial salary. To underline the novelty of this measure, it must be remembered that participation in the labor force was compulsory for adult men as well as women in the Soviet Union (no more than 3 weeks of interruption in employment was legal). Granting mothers 18 months for child care was indeed a generous provision, quite different from the policies which aimed at mobilizing all women in the labor force. At the same time, the birth allowance was extended to all births, including the first parity. Improvement of reproductive health services was targeted as well. However, access to modern contraceptives still remained poor.

Housing policy was another important instrument in the attempts to influence fertility. Controlling the distribution of new apartments, the state took several steps to improve the housing conditions of young families with children. According to the regulations, newly married couples (up to age 30 ) were eligible for separate space of their own, and a flat, if a child was born in the three first years of marriage. Young families were also given priority in joining the housing cooperatives. In short, the Soviet practice of granting privileges to certain population groups by means of housing was extended to young families for the first time.

Against the background of new policies, fertility development in the 1980s deserves attention. In Estonia, the fertility of the native population witnessed a slight downward trend. The foreign-origin population, however, experienced an increase in fertility, and towards the end of the decade caught up with the native population, bringing the difference - observed since the late 1960s - to an end. The convergence of fertility levels between the two sub-populations resulted in the rise of fertility to its highest level over the past seven-eight decades in Estonia (Katus, Puur and Põldma 2002). The possible connection between the introduced measures and fertility increase among Slav population still remains hypothetical. However, much more likely is the impact 
of policies on fertility timing. There was no shift towards the aging of fertility as in other countries with similar population development.

In the Estonian context the change in child- and fertility-related policies in 1982 could be regarded as a repetition of the innovation of the 1930s. The rationale behind the introduction of new policies was similar - on both occasions society sought a response to under-replacement fertility. Interestingly enough, the distance between the two beginnings closely follows the four-five decade time lag in demographic development between Estonia and Russia. Comparing the two beginnings, the first one was accompanied by wide public discussion and consolidation of views. Also, in relative terms child allowances introduced in the 1930s exceeded those in 1980s. However, not all population groups were covered by the system. Further, population information and research played rather different roles: in contrast to the thirties there were strong restrictions in the access to population data in Soviet Union, maintained until the late eighties (Veskimägi 1996). In Estonia, there was no population science as a separate scholarly discipline.

\section{Shift of orientation from the family to the individual}

The concern about low fertility, depopulation and large-scale immigration etc became a debated issue in the struggle for independence in Estonia starting in 1987-1988. Among others, Lennart Meri expressed these concerns in his program speech at the assembly of intellectuals (LP 1988). Concern for the future of the nation under the continued Soviet occupation was well founded and widely shared. However, the knowledge base in the population field, including the comprehension of demographic information, was rather poor - an outcome of prolonged restrictions on data availability. An emotional approach to population issues prevailed in that period, and unrealistic aims were frequently aired. These aims were summarized in a popular song calling for people to fill the country with children.

A series of laws and regulations was initiated starting from 1987, proposing various measures to improve the demographic situation. The last one in this series was the law on child allowances, enforced already after independence in 1992 (RT 1992, no.6). Taking into account the predominance of an emotional rather than a methodological and/or knowledge basis, it is not surprising to find that policy measures introduced in the late eighties and early nineties were conceptually an extension to those applied in the Soviet Union in 1982. For example, several types of cash allowances were defined in absolute terms, without foreseeing the procedures of indexation. Also, the measures under different ministries were fragmented, sometimes even contradicting each other. 
The transition to a democratic society and a market economy was one of the factors invalidating most of the instruments of child- and fertility-related policies described above. For example, the emerging housing market together with the collapse of staterun construction of apartments abolished one of the key instruments for influencing the living conditions of young families. Also, the right to stay at home and take care of a child - extended to 3 years in 1989 - lost its meaning when compulsory workforce participation was replaced by the labor market. Under emerging unemployment, long periods out of work ceased to be a privilege and involved difficulties in re-integrating into the labor force (Puur 2000). Following the currency reform in 1992 the social benefit systems were reconsidered, with low priority given to family and child allowances.

Thus, rather paradoxically, in the 1990s one of the central concerns of the independence movement - low fertility and depopulation - received hardly any of the attention it had received previously. What was left was the post of Minister of Population Affairs in the government, and the equal access to social protection among native and immigrant population, regardless of citizenship. With respect to the latter, social policies in Estonia are more generous than those commonly practiced in EU countries. In the second half of the 1990s, explicit discord between the public and policy-makers started to develop with respect to population issues. On one hand, the sharp fertility decline and intensive depopulation, poor integration of immigrants, controversial developments in population health etc. formed a platform for increasing public concern. On the other hand, the recognition of difficulties in achieving the results - particularly over a short-term perspective, including the cycle of elections - made many politicians and even some parties in corpore cautious about taking any initiatives in the field of population. In public, such an attitude was regarded as deficit of statesmanship.

In the recent parliamentary elections (2003), politicians chose to respond to negative developments in the population field and growing public concern. All leading political parties addressed population issues, particularly low fertility, in their campaigns. After the elections, somewhat surprisingly, the coalition government reserved the position of the Minister for Population Affairs for the Reform Party, which during the 1990s had neglected population related policies. The office of the Minister was staffed by enthusiastic youth affiliated to the same party, who singled out mother's salary and promoted it with a noticeable PR-campaign. The Minister informed the European Population Forum about the program to reach replacement fertility in Estonia (PMB 2004).

The new policy focused much on one issue: enforced in January 2004, it introduced the payment of a full salary during the first year following childbirth. Public criticism derived mainly from the large differences in the amount of benefits paid, for example, 
to non-employed or student mothers (minimum salary) and highly remunerated employees (up to three average salaries). At the expert level, it was pointed out that the introduced measure does not fit into the existing system of social allowances, and that it increases the already high income inequality. Indeed this was the first time in Estonia when measures in the field of child- and fertility-related policies have met with excessive criticism from the populace.

\section{Population aging and the elderly}

In this section, responses to demographic aging are viewed mainly from the viewpoint of the pension system and elderly care. Usually, the development of the pension system is closely connected with the societal regime. In Estonia, three main stages in the development of the pension system include the period of independence, occupation and regained independence.

\section{Institution of a pension system}

In the 1920s, Estonia started to develop its pension system essentially from scratch. In the Russian Empire limited categories of the population, covering some of the government employees and war invalids, had been entitled to pensions. However, these entitlements should be regarded as exceptions rather than a system. Even for these categories the successor of the Russian Empire denied responsibility for the payment of pensions. Pension capital had also been lost.

The pension system established in the early 1920 s covered central and local government employees, teachers, workers in state enterprises, war invalids and military personnel, together with family members (RT 1920, no. 77/78; 1924, no. 123/124; 1926, no. 23). The system foresaw the payment of old-age, disability and survivors' pensions. According to general rules, persons 60 years of age, both men and women, with 25 years' service were entitled to full old-age pension (Buldas 1934). Pension expenditures were covered from the pension fund, which received allocations from the state budget (about 3/4 of the input) as well as employers' and employees' contributions (about 1/4). Also, the government assumed responsibility for the payment of benefits to those who had been entitled to pensions under the laws of the Russian Empire.

As the system matured, it witnessed a rapid growth in the number of benefit recipients. In contrast to the modern pattern, men constituted almost 90 percent of pensioners in that period (Tuisk 1931; Lepp 1936). Another trend was the increase in the proportion of old-age pensioners and the decrease in recipients of disability and survivors' pensions who at the outset constituted the overwhelming majority 
of pensioners. A new Pension Law was passed in 1936 (RT 1936, no. 76), and in accordance with socio-economic development, the system was further improved. In 1939, for example, the coverage of old-age and disability pensions was extended to all industrial workers in private enterprises with six or more workers. According to the law, employers in medium and big enterprises were obliged to provide a monthly old-age allowance to workers who had reached age 65 and were not able to support themselves.

The issue of public relief, including care for the elderly, was addressed by the Social Welfare Law passed in 1925 (RT 1925, no. 120/121). The law was based on family members' mutual responsibility and described in essence a social policy with assistance provided on the basis of tested means. Regarding the elderly, every man and woman aged sixty or over in need was entitled to assistance. The primary responsibility for the care of persons who could not manage by themselves and lacked the support of family/kin was assigned to the municipalities, which had performed this function already since the 19th century. However, it is necessary to underline the important contribution made by various voluntary organizations and the church (Pullerits 1927). The development of social welfare was further influenced by the beginning of social work education.

Generally assistance was aimed at enhancing self-support, and correspondingly, considerable attention was paid to the development of open care. In the 1930s, the total number of persons receiving assistance under public relief amounted to five percent of the population, and of that overall number approximately four fifths were assisted in the form of in kind support (Tuisk 1937). The network of institutional care units included institutions for the elderly and disabled, institutions for war invalids, residential homes for the elderly and temporary asylums. The most widespread types of institutions were welfare accommodations. Such dwellings, in essence former poorhouses of municipalities, were accompanied by a plot of land which was used by the residents.

\section{Contradictory developments in the pension system}

The annexation of Estonia into the Soviet Union brought the existing pension and social welfare system to an end. A majority of beneficiaries under the former system were denied their pension rights, moreover government service in the Republic of Estonia was criminalized (RKN 1945). The discontinuity resulted in a decrease in the number of pensioners, the size of pensions dropped noticeably and often those that were awarded were below subsistence level. 
In 1956, the Soviet Union enforced a Pension Act which thoroughly revised the existing system, increasing substantially the level of benefits and improving the economic situation of the elderly. Still, the new pension system was neither universal nor uniform (Porket 1979). The system was restricted to the working population who had accumulated the required employment record. To be eligible for a full old-age pension, males were required to be 60 years of age and have an employment record of 25 years, while for females the age limit was 55 years. The system did not apply to collective farmers who, with their dependants, constituted about one third of the population. It was only in 1965 that a state pension was extended to collective farmers, and it took until the 1970s until the two systems were merged with respect to eligibility rules ${ }^{5}$.

The eligibility criteria kept the number of old-age pensioners initially rather low, as several types of economic activities were considered non-productive or even counterrevolutionary, and consequently a large part of the older population was left without an employment record. Around 1960, for example, beneficiaries accounted for one third of the population in retirement age. The proportion grew constantly, and by 1970, a pension had become the single most important source of livelihood for both males and females above age 60. In the 1980s, a broad coverage characteristic of universal systems was achieved. It should be noted, however, that the driving force behind this trend was not the increase in the generosity of the pension system, but the cohort flow which gradually shrank the groups of older persons not entitled to pensions and replaced them with younger generations. The latter had experienced high workforce participation during their lifetime and this met the compulsory service requirement (Puur 2000).

Another characteristic feature of the pension system enforced in Estonia relates to the pension formula. The formula was redistributive from higher-income to low-income earners and the system was aimed towards avoiding poverty and providing minimum protection rather than securing the replacement of labor income. Considering the weak link between the contribution and individual benefit, one could also assume a relatively limited differentiation. However, in reality, there was much less equity than one would expect. To this end it is interesting to note that among the CEE countries, the Soviet Union featured a relatively high degree of income inequality already prior to the economic transition (Atkinson and Micklewright 1992).

This paradox stems mainly from the lack of indexation which reflected the false assumption of zero inflation in centrally planned economies (Schmähl and Horstmann 2003). The lack of adjustments resulted in remarkable differences across the groups

\footnotetext{
5 Originally, under the 1964 Act, the retirement age was set at 65 for male collective farmers and 60 for female collective farmers.
} 
of pensioners - the longer a person had been retired, the lower his or her pension in relative terms. To a certain extent workers attempted to compensate for this by inflating their reference wage during the last year of employment. This was achieved by various means, ranging from multiple jobholding to changing to better rewarded jobs. Results published elsewhere indicate that these efforts were to some extent successful as the replacement rate of the average pension to the gross wage increased by nearly 10 percentage points in the 1970s and 1980s (Põldma 2000).

The lack of regular adjustment also explains the discrepancy between statutory and actual retirement age. In contrast to developed market economies, it became increasingly common in Estonia in the 1970s and particularly in the 1980s to postpone withdrawal from the labor force beyond statutory retirement. At the eve of transition, the median of withdrawal from the workforce had reached 66.2 years for males and 62.1 years for females in Estonia, corresponding to 7 and 11 years after statutory retirement (Katus et al. 2003). Also, this trend was supported by the authorities who sought ways to alleviate the chronic shortage of labor, characteristic of centrally planned economies. Among young olds, simultaneous receipt of labor income and old-age pension secured a relatively high living standard.

As regards social welfare, the role of municipalities and non-governmental organizations was abolished and the system became strongly centralized. All activities which lacked a parallel in the Soviet model were canceled - this includes the network of welfare accommodations, the system of foster family care; even the training of social workers ceased in 1951. For the older population, outpatient services were neglected and institutionalization became the sole option.

In the Soviet model, residential homes for seniors and the disabled had largely became medical-type establishments, with relatively poor service, however. The development of the institutional care network was based on all-union standards, disregarding the more advanced stage of population aging in Estonia compared to other republics. Together with the absence of outpatient care and home services, this resulted in a situation where even those who were eligible were denied admission and long waiting lists were commonplace. In the late 1980s among the oldest-olds $(85+)$ the proportion of institutionalized persons did not exceed five percent (Katus et al. 2003). From the viewpoint of the elderly, institutionalization involved almost complete loss of autonomy as 90 percent of their pension was deducted for the expenses of the institution and rights to an apartment were abolished (Bachverk and Saia 1988). The concentration of care into large units typically meant a move to another location and loss of previous social networks. As a result, institutionalization was highly unpopular and the bulk of the demand spilled over to families and kin. 


\section{Crisis management and structural reform}

Towards the end of the 1980s, the emerging crisis of state socialism became clearly apparent also in the pension system. Although the nominal old-age pensions went on rising, the real value could no longer keep up with accelerating inflation. The leadership in Moscow realized that the existing system of social protection needed changes. In 1989 a new pension law was ordered, but the situation was beyond remedy.

The collapse of the command economy pushed the replacement ratio of the average old-age pension down from 36 to 16 percent, and the situation was even more aggravated by other factors. Extremely rapid inflation (20,000 percent in 1989-1992) resulted in an almost complete loss of savings. This development hit the older population with disproportionate severity: unlike those of working age, the elderly were hardly able to make up their loss. Also with respect to economic activity, the loss of employment opportunities was largest in older age groups ${ }^{6}$. The third factor adversely affecting the living standard of the older population, but also other groups with no labor income, was the deregulation of prices and abolition of subsidies for basic commodities and housing, implying a sharp restructuring of consumption patterns.

Work on new pension regulations was started in 1990. As the local expertise on pension system and social protection was limited, the draft of the new Soviet pension law was enforced in April 1991 (Leppik and Männik 2002). In a few months, however, the new law proved to be invalid. As an emergency solution, in February 1992 the Parliament suspended the pension law, and introduced flat-rate benefits and all old-age pensioners were paid a similar amount. Reflecting the general dissatisfaction, in 1993, the flat-rate system was revised and some differentiation introduced according to length of service. In fact, the departure from a flat-rate benefit was very limited, and the differentiation of pensions remained very low in Estonia, except for the MPs, judges and state auditors, who have separate systems.

The revision of 1993 was more important from another point of view. The major change introduced was the raising of the statutory retirement age by five years, to 65 for males and 60 for females. The increase was initially scheduled for the period 1994-2003, but later postponed until 2007. The increase in the age of retirement was intended to reduce the burden on the pension system, caused by a sharp acceleration of demographic aging (Katus et al. 2003). The latter stems from the large immigrant cohorts, which had arrived in the country in the late 1940s and 1950s,

\footnotetext{
${ }^{6}$ While the decrease in the employment rate among those of prime working age was limited to 5-8 percent, the proportion employed among those aged 60-64 dropped by nearly two fifths, and among those aged 65-69, only 40 percent of those initially employed remained. As a result, actual retirement transition shifted down 3-4 years towards a younger age (Katus et al. 2003).
} 
entering retirement age. The increase of retirement age helped avert extreme poverty among the older population. Compared to other vulnerable groups, for example, the unemployed and single-parent families, the poverty rate appears lower among the older population; the oldest olds have even improved their relative incomes during the transition period (Puur 2000).

In 1998, the Parliament adopted a reform based on a three-tier pension system (RT 1998, no. 87). The first tier is based on a pay-as-you-work-principle and aims at securing a minimum standard of living for all seniors. It is financed by four fifths of the 20-percent social tax. The second tier relies on individual contributions into privately managed pension funds. Participation in the second tier is compulsory for the cohorts entering the labor market: participants pay individual contributions of 2 percent of their gross wage. Individual contributions are supplemented by the state with 4 percent of the gross wage, which is re-directed from the social tax. The third tier aims at encouraging additional savings for old age, stimulated by tax deductions.

The new revision of the system introduced equal pensionable age of 63 years for both sexes. By now, about half of the employed have joined the second tier, and the third tier covered about one tenth of the employed. Despite the successful implementation of the reform, however, the second and third tier are expected to have a significant effect on the situation of seniors after some decades when the new cohorts have had time to accumulate the respective resources (Leppik and Kruuda 2003). At the same time, the differentiation of pensions will increase as the existing wage differences are translated into the amounts of benefits. This calls for greater attention to the social adequacy of minimum pensions, and together with the desire to improve the situation of elderly cohorts who have retired or will retire in the next decade, will evidently strengthen the demand for tax increases.

Changes in policy orientation have occurred also in the field of social welfare. The primary responsibility for the provision of services has shifted from the state back to municipalities and voluntary organizations have also resumed their activities. The trend towards decentralization is evident. For example, the number of institutional care facilities increased from 18 to 81 during the 1990s. From the viewpoint of seniors, this has meant smaller facilities which are often situated closer to a person's usual residence. Another important feature of these new developments has been the shift from medical-type institutions to institutions providing a wider choice of services, including outpatient services. In 1997, the number of persons using outpatient services exceeded the number of institutionalized seniors (ESA 2003). Municipalities have started to establish daycare centers. Furthermore seniors can apply for residence in special apartment blocks where they can be assisted by a social worker and benefit 
from a range of services. On the other hand, despite positive shifts in the structure of services, the demand continues to exceed the supply.

\section{Public health}

This section addresses the development of policies in the field of health care. As in the domains discussed above, the decades since the early 20th century have witnessed repeated changes in the corresponding regulations, on one hand, and the transformation of mortality and morbidity patterns, on the other. Based on the interplay between policies and population health, the period has been divided into four major stages.

\section{Establishment of a national health service}

Estonia had no modern public health service to inherit from the Russian Empire, which made it necessary to make a completely fresh start. Among the first institutions the government established was the health department, which was given the task of developing the concept for national public health organization. Since 1920 the department was assisted by the National Health Council - an academic advisory board which guided the reform and all issues related to hygiene, therapy, pharmacy and medical research, including jurisprudence and legislative measures (Riigikantselei 1935).

The primary responsibility for the provision of health services and administration was given to the municipalities. The country was divided into health districts of 6-8 thousand inhabitants, headed by a district medical officer. The district medical officers organized public health services in their district, carried out the duties of school physician, performed sanitary control, gave free treatment to the poor etc. Larger municipalities and counties established health boards, working in close cooperation with the municipal/provincial medical officer. After ten years of experience, the principles of the national public health organization were codified in the Public Health Promotion Law (RT 1928).

In the framework of national organization, the interwar period witnessed considerable progress in the number of medical personnel and facilities. By the late 1930s, the number of doctors had increased two and half times and the number of trained nurses more than sixfold. The right to have a medical practice was only given to persons who had completed the full university course, lower sanitary personnel were also required to have the necessary professional qualifications. In terms of research, comprehensive studies on public hygiene were prepared, covering the whole country by comparative county studies (Rammul 1929-1938). 
Public health policies developed in the interwar period put a major emphasis on the promotion of public hygiene. Protection of motherhood and of children was also strongly prioritized, as discussed earlier. In the field of school hygiene, annual health inspections were introduced at the beginning of each term, all sick pupils obtained free treatment. In the field of industrial hygiene, new legislation was passed concerning working conditions, working hours, medical assistance in case of industrial accidents etc. (Kaelas 1938). Activities in the field of preventive care included the development of health resorts and sanatoriums, and health promotion work was done in close cooperation between public and civil society organizations (Pullerits 1935).

In terms of financing, the system of health insurance was reorganized. At the beginning, compulsory insurance covered central and local government employees, workers in enterprises with 20 or more employees as well as their family members. In 1923, it was extended to workers in small businesses. The health insurance tax totaled four percent of the payroll, with the payment of the tax shared equally between the employer and employee. Insurance against work injuries was covered fully by the employer. In case of sickness (and childbirth), the insured received medical treatment and pecuniary aid to compensate for lost income. The development of the system was reflected in increased coverage: by the late 1930s the number of insured persons and their family members had passed 18 percent of the total population (Raid 1939). The population not covered by the insurance system was expected to bear their own medical expenses, but if the resources were not available, the cost was borne by the municipalities.

\section{Health crisis related to societal discontinuity}

Geopolitical rearrangements accompanying WWII introduced a different model in the organization of health care which persisted until the 1990s. Before addressing that change, however, it is worthwhile drawing attention to the impact of societal discontinuity on population health.

The magnitude of the direct health impact can be approximated by population losses imposed by the war and repressions. It has been estimated that Estonia lost about one fifth of its pre-war population (Katus 2002). The discontinuity of the population stock, however, has not yet allowed translation of these losses into mortality indicators, but the related research done for other parts of the Soviet Union can give some idea about the extent of the crisis. For Ukraine, for example, the research has revealed that in the early 1930s, male life expectancy at birth dropped to seven years (Meslé and Vallin 2003).

Regarding Estonia, the upsurge of mortality can be followed using the infant mortality rate which is often used as a general measure of societal conditions. In the 
immediate postwar years infant mortality increased by more than 50 percent compared to the war period (Katus 2000). Also, judging from the absolute number of recorded deaths, it can be concluded that the health crisis in Estonia culminated in 1946-1947. The peak of mortality in the postwar years rather than during wartime was uncommon in Europe.

Aside from the mortality increase, a considerable health impact resulting from various hardships experienced in the war, prison, labor camps and deportation can be assumed. This indirect effect was accumulated in the population and the survivors carried it along with them throughout their lifetime. In public health research in Estonia this effect has not been addressed in detail yet but it can be hypothesized that the experience accumulated in the 1940s and 1950s has contributed to disfavorable mortality development in the following decades.

\section{Shift towards a centralized and treatment-oriented system}

The health care organization which was instituted in Estonia after WWII originated from the context where mortality from infectious diseases and other exogenous causes was strongly prevailing. The institution of the Soviet model in Estonia meant the nationalization of all hospitals, clinics, sanatoriums and other health care units. Although private medical practice was not formally prohibited, high taxes and other restrictions made it soon marginal. Health care was funded from the state budget and care was declared free of charge.

Among other important changes, the new model dissolved the local organization under which municipal/county medical officers had dealt with a broad range of issues in the field of public health and hygiene, in cooperation with the local administration. In the new model, the responsibilities of the system shifted from public health to curative medicine and the operation of medical institutions. Health care was heavily hospital- and specialist-care oriented, and parallel with the advancement in the methods of treatment, this orientation showed a tendency of strengthening over time.

In the development of the health care system, priority was given to quantitative aspects such as the number of doctors, hospital beds etc. Although the war and repressions took a heavy toll - according to Merila-Lattik (2000) the number of doctors had dropped more than twice in 1939-1945 - quantitative characteristics of the health care system showed persistent growth throughout the postwar decades. The number of hospital beds, for example, reached 11.9 per thousand of the population, which exceeded the corresponding level in most European countries. As it has turned out later, a considerable part of the increase in capacity occurred in small and poorly equipped facilities. Similar to other sectors, the health care system foresaw separate hospitals and outpatient clinics for privileged categories of people. 
Mortality indicators show, however, no positive contribution from the expanding health care system. In the beginning of the 1960s the growth in life expectancy ceased and the following four decades have shown no noticeable improvement in Estonia (EKDK 2004). This phenomenon has been widely documented in the countries of Central and East Europe but, together with Latvia, the relatively early timing of the demographic transition has contributed to a particularly long mortality stagnation in Estonia. Although the ultimate cause of the stagnation remains hypothetical, mortality trends leave no doubt about the failure of health care policies in improving the population health in Estonia.

\section{Recent health care reforms}

The reform of the health care system started from the Health Insurance Act in 1992 (RT 1992, no. 63). According to the new regulation, an earmarked health insurance tax, amounting to 13 percent of the payroll was imposed, payable as part of the 33-percent social tax. The health insurance funds contract medical institutions that are paid according to the services they provide and small patient fees are used as co-payment. The major advantage of the introduced system was the detachment of payment from the service provider. However, this introduced potentially distortive market incentives (Vask 1998). The shift to health insurance did not imply any major changes in the coverage of the system. By and large, the entire population (about 95 percent) is covered by the insurance, including the foreign-origin population not holding Estonian citizenship (Kiivet and Harro 2002).

Based on the principles of solidarity and limited cost-sharing, the insurance covers the cost of curative and preventive health services as well as for compensation of pharmaceuticals and technical aids, and payment of cash benefits in case of temporary work incapacity. Due to the coverage and extensive package of services provided by public insurance, the market for voluntary/private health insurance is very small. Persons who are not covered with insurance are entitled to free emergency medical assistance.

The transition has witnessed a considerable restruction of facilities. The changes in hospital sector are aimed at the quality of service by centralizing acute inpatient care on one hand and creating a system of nursing care on the other hand. Since 1990 the number of hospitals and hospital beds was reduced almost by half, which makes this the most rapid decrease among the CEE countries (Leppik and Kruuda 2003). To facilitate the investment in modern equipment, the reform foresees further concentration of acute care into 13 units, and advanced treatment into four regional hospitals by 2015. The plan also envisages the conversion of some of the current acute care hospitals into long-term care institutions. A restruction of the primary care system replaced the system of outpatient clinics with family practicians. The 
objective of the reform was a clearer responsibility for the patients and a shift in the balance from secondary and tertiary to primary care (WHO 2001).

Regarding health care personnel, the number of physicians has decreased by 15 percent since 1990, with the main reduction in 1992-1993. The only exception to the general trend are dentists - about three fourths of them work in private practice - who have increased their number by about the same proportion. The largest decrease (20 percent) was among nursing staff, aggravating the already distorted ratio of nursing staff and doctors (SM 2000). While the relative number of physicians is close to the European average, Estonia has only half of the qualified nursing staff to provide adequate support for patients and secure an optimal division of responsibilities.

Against the background policy reforms, the developments in public health indicators have been controversial. In the first half of the 1990s, Estonia featured an upsurge of mortality which peaked in 1994 (Katus and Puur 1997). Particularly extensive deterioration was experienced by males (life expectancy dropped to 61.1 years). Since the mid-1990s, mortality indicators have shown some progress, reaching the previous levels characteristic of the period of mortality stagnation.

The mixture of progress and serious concerns can be observed also with respect to specific fields of public health. Over the past decade, the physical environment has become healthier and air and water pollution have decreased. Estonia has featured a noticeable decline in infant mortality, the use of modern contraceptives has increased and the number of induced abortions has been falling steadily (Tellmann et al 2003). In recent years, Estonia has witnessed a rapid increase in the incidence of HIV/AIDS infection, overwhelmingly among the foreign-origin population, which coincides with drug abuse. The spread of the infection shows that prevention programs have failed to address the issue. Smoking has declined among adults but is increasing among the school-age population. Also alarming is the frequency of experimentation with alcohol and drugs among youth (Allaste 2000). The eating habits of Estonians have become healthier but new opportunities are not available for large groups of the population.

Persistently low life expectancy and concerns in public health present a constant major challenge to health policies in Estonia. The introduction of market principles brought financing to the top of the agenda in the health sector and created a tendency to regard all issues - investments in new technology, waiting lists for treatment, the balance between primary, secondary and tertiary care etc. - from the viewpoint of funding. Regarding the future, rapid aging of the population and the shrinking number of taxpayers add a new challenge to the sustainability of solidarity-based health insurance. Pressures on the system also arise from higher expectations concerning 
the quality of medical care. Under these circumstances it takes strong commitment to secure access to high-quality medical service for the entire population.

\section{Discussion and conclusions}

The general conclusion from the overview presented here leaves no hesitation that major discontinuities which have shaped the societal landscape of Estonia are explicitly manifested also in the realm of population-related policies. In all policy sectors covered in the paper, the development of policies has started anew three times during the 20th century - first, in the 1920-1930s when Estonia made its way towards becoming a modern nation, second, in the postwar decades when the country was drawn into the state-socialist venture, and third, in the years of the current societal transformation. Although the circumstances and the lengths of the periods have varied, each turning point has rendered the existing institutions and arrangements obsolete and introduced a basically new regulation.

This discontinuity and the institution of an imported model have prevented Estonia from developing a policy regime which would take appropriate consideration of prevailing national circumstances and traditions. The neglect of the needs ensuing from population development, behavioral patterns and preferences was highlighted in the previous sections. During the past decade and a half the country has faced new challenges. In the field of social and population-related policies, Estonia has been influenced by the Scandinavian model, as noted in the well-known categorization of Esping-Andersen (1990). But at the same time, there also have been some influences of Central European corporatistic model, and also of the Anglo-American liberalistic model, which to an important extent represents an antipode to the previous regime. In decision-making circles each model has its supporters and critics, but more importantly, whatever the model preferred, the building of a welfare society is noticeably hampered by the legacy of the former regime.

The major difficulty in developing population-related and social policies stems above all from the imbalance between demographic and economic development in Estonia. From the population perspective, the high proportion of older population, lowest low fertility and acute depopulation, the prevalence of chronic illnesses, modern patterns of family and intergenerational relations etc. imply a considerable need of resources for pensions, health care and other social expenditures. From an economic perspective, however, Estonia is experiencing the stage of primary capital accumulation. This occurs for the second time in the nation's history, but now under remarkably different demographic circumstances. Compared to the average of CEE countries, this imbalance appears more pronounced in the case of Estonia - among the 
forerunners of the demographic transition, Estonia and Latvia were the only countries left behind the Iron Curtain. As a consequence, population and social programs will have to compete for limited resources with other urgent needs of nation-building, ranging from education to state defense.

Another essential constraint refers to the heterogeneity of the population. For four decades since the late 1940s, Estonia was a destination for mass immigration from various parts of the former Soviet Union. As elsewhere in European immigration countries, structural characteristics and behavioral patterns of immigrants and their descendants differ systematically from those of the native population, and vary across subgroups of the foreign-origin population (Katus, Puur and Sakkeus 2002; Viikberg 1999). In contrast to the latter countries, persistently large flows have resulted in remarkably high proportion of immigrants, accounting for 36 percent of the total at the eve of transition. This differs even more markedly from the prevailing situation in the CEE region, which has only recently been transformed from being an area of emigration to one of immigration. In the case of Estonia, the presence of a disproportionate foreign-origin population indeed calls for comprehensive integration programs which are known to be costly and involve substantial public expenditure. But more importantly, low adaptation to the host society which has been inherited from the past is manifested in virtually all kinds of social distress, including unemployment, crime, drug use and HIV/AIDS. Needless to say, due to the size of the foreign-origin population, this adds to considerable strain on corresponding social programs.

Aside from objective factors, the development of population-related policies has been complicated by the lack of expertise, particularly in the early 1990s. Similar to a number of other areas, policy development and planning were concentrated with the central authorities in Moscow, and the local administration in Estonia was charged with the implementation of existing regulations. It is important that such a situation was not characteristic of the majority of CEE countries which had maintained their statehood within the Eastern bloc. Re-integration into the international community was accompanied by a stream of proposals flowing in from various countries, consultants and international agencies with different historical backgrounds and policy arrangements. Due to limited local expertise, the recommendations were not always critically assessed in terms of their appropriateness to circumstances prevailing in the country.

If one would compile a balance sheet on the policy development during the recent decade, both achievements and shortcomings must be noted. On the credit side, Estonia is frequently mentioned as an example of successful management of transformation. Reforms implemented in the early 1990s resulted in a rapid departure from central planning and macro-economic stabilization. Regarding social policies, it implied a change in principles and organization. Despite the transformation, however, the coverage of basic protection systems was not significantly reduced. 
Relatively active participation in the voluntary second tier of the pension system provides an example of raising self-responsibility and shifting to individualized risk-bearing. Positive developments can be found also in demographic and social processes; for example, the persistently falling abortion rate indicates improvements in reproductive health.

On the reverse side, the imbalance between population and economic development has set strict limitations on resources and resulted in a residual population-related and social policy. For the same reason there is no quick and easy fix to the situation, and the principal improvement can be achieved only over a longer run, through structural reforms. The management of transformation, however, has not been smoothly followed by carefully planned reforms in all major policy sectors. An example can be provided by the field of fertility and childbearing where the emphasis has shifted to a few direct measures, at the expense of a broad range of indirect influences and a long-term perspective. Even in the sectors with a better record of success, for example, in the pension system, the implementation of the reform plan was delayed for several years and several important issues, such as the social adequacy of pensions for low-income earners, an indexation mechanism in the first tier etc., are not yet properly addressed.

A long-term perspective required for successful structural reforms underlines the importance of policy continuity, irrespective of the change of actors. In the representative democratic system, however, politicians with an eye on the next elections are forced to demonstrate short-term success and gain the sympathy of the electorate. To overcome or at least alleviate pressures to trade between short- and long-term as well as national and more specific interests, successful reforms demand a consensus among political actors about the strategic goals and their implementation. Over a few recent years, the need for such a consensus has been increasingly acknowledged and its scope and content have come under debate in Estonia.

In May 2004, Estonia joined the EU. This is a very important step in overcoming the heritage of the Teheran-Yalta deals. The direct implications of the accession on population-related and social policies should not be exaggerated. In the EU, the regulations in these areas are left to a considerable extent to the discretion of member countries, and the minimum requirements established for benefits are defined in relative rather than absolute terms. Except for some systems (e.g. unemployment, disability and survivors benefits), the established minimum standards are met in Estonia. Against that background, indirect implications of the EU accession may have greater importance. This involves a shift towards a paradigm according to which population-related and social policies are regarded not solely as a financial burden but more importantly as an investment into human resources and welfare which is necessary for sustainable development. 


\section{References}

Allaste, Airi (ed). 2000. Uimastite levik noorsoo hulgas. Tallinn: Rahvusvaheliste ja Sotsiaaluuringute Instituut.

Atkinson, A. and J. Micklewright. 1992. Economic Transformation in Eastern Europe and the Distribution of Income. Cambridge: Cambridge University Press.

Bachverk, Georg and Endel Saia. 1988. Soodustused invaliididele ja vanuritele. Tallinn.

Bradley, David. 2001. Regulation of Unmarried Cohabitation in West-European Jurisdiction - Determinants of Legal Policy. International Journal of Law, Policy and the Family 15(1):22-50.

Buldas, Aleksander (ed). 1934. Pensioniseaduste- ja määruste kogu ühes neisse puutuva Riigikohtu senise praksisega. Narva: M.M. Minkis.

Calot, Gérard, Alain Confesson, Jean-Paul Sardon, Erminio Baranzini, Stéphane Cotter, and Philippe Wanner. 1998. Two centuries of Swiss demographic history. Bern: Bundesamt für Statistik.

Council of Europe. 2003. Recent Demographic Developments in Europe. Strasbourg: Council of Europe.

EKDK. 2004. Life Tables. Estonia 1923-1938 and 1950-2000. RU Series C, no. 22. Tallinn: Eesti Kõrgkoolidevaheline Demouuringute Keskus.

ESA. 2003. Sotsiaalne kaitse. Tallinn: Statistikaamet.

Esping-Andersen, Gösta. 1990. The Three Worlds of Welfare Capitalism. Policy. Oxford: Polity Press.

Granström, Fredrik. 1997. Fertility and family surveys in countries of the ECE region. Sweden. New York and Geneva: United Nations.

Kaelas, Aleksander. 1938. Töökaitse seaduste ja määruste kogu. Tallinn.

Kahk, Juhan and Enn Tarvel. 1997. An Economic History of the Baltic Countries. Studia Baltica Stockholmiensia, no. 20. Stockholm University.

Katus, Kalev. 1997. Long-term fertility development in Baltoscandia. Yearbook of Population Research in Finland, pp. 18-35. Helsinki: The Population Research Institute.

Katus, Kalev. 2000. Long-term mortality trend in the Baltic countries. Trames 3:231-56.

Katus, Kalev. 2002. Eesti rahvastiku areng Euroopa kontekstis. In: M.Veiderma (ed). Eestile mõeldes. Vabariigi Presidendi Akadeemiline Nõukogu 1994-2001. Tallinn: Vabariigi Presidendi Kantselei, 1k. 35-48.

Katus Kalev. 2003. Post-transitional fertility development: new perspectives introduced by Central and East European nations. In: Population of Central and Eastern Europe, edited by I. Kotowska and J. Jozwiak, pp. 117-38. Challenges and Opportunities. Warsaw: Warsaw School of Economics.

Katus, Kalev and Allan Puur. 1997. Mortality development and economic transition: the case of Estonia. RU Series B, no. 35. Tallinn: EKDK.

Katus, Kalev and Allan Puur (eds). 2003. Unity and diversity of population development: Baltic and South-Caucasian regions. RU, Series D, no.3. Tallinn: EKDK, pp. 49-158.

Katus, Kalev, Allan Puur, Asta Põldma and Luule Sakkeus. 2003. Population Ageing and Socio-Economic Status of Older Persons in Estonia. New York and Geneva: United Nations.

Katus, Kalev, Allan Puur and Asta Põldma. 2002. Eesti põlvkondlik rahvastikuareng. Tallinn: EKDK.

Katus, Kalev, Allan Puur and Luule Sakkeus. 2002. Immigrant population in Estonia. In: The demographic characteristics of immigrant populations, edited by W. Haug, P. Compton and Y. Courbage, pp. 131-92. Strasbourg: Council of Europe. 
Kiivet, Allan and Jaanus Harro (eds). 2002. Health in Estonia 1991-2000. Tartu.

Kotkas, Vaike (ed). 2000. Järvamaa aastal 1939 ja nü̈d. Tallinn: Eesti Muinsuskaitse Selts.

Kullerkupp, Kai. 2001. Family Law in Estonia. In: The International Survey of Family Law, edited by A. Bainham, pp. 95-110. Bristol: International Society for Family Law.

Laaman, Eduard. 1964. Eesti iseseisvuse sünd. Stockholm: Tryckeri AB Esto.

Lepp, A. 1936. Pensionid. Eesti Statistika, no. 10, lk. 498-507. Tallinn: Riigi Statistika Keskbüroo.

Leppik, Lauri and Ruta Kruuda. 2003. Country Study: Estonia. Social Protection in the Candidate Countries: Estonia, Latvia, Lithuania. Berlin.

Leppik, Lauri and Georg Männik. 2002. Transformation of Old-Age Security in Estonia. In: Transformation of Pension Systems in Central and Eastern Europe, edited by W. Schmähl and S. Horstmann. Cheltenham and Northamptom: Edward Elgar.

LP. 1998. Eesti NSV loominguliste liitude juhatuste ühispleenum. Tallinn: Eesti Raamat.

Lundström, Hans. 1999. Befolkningsutvecklingen under 250 år. Stockholm: Statistiska Centralbyrån.

Maasing, Richard (ed). 1954-62. Eesti riikja rahvas teises maailmasõjas (1954-1962). Vol $I-X$. Stockholm: EMP.

Madisson, Hans (ed). 1935. Eesti rahva tulevik. II rahvusliku kasvatuse kongressi kõned ja läbirääkimised. Tartu: Eesti Eugeenika ja Genealoogia Selts.

Must, Aadu. 2000. Eestlaste perekonnaloo allikad. Tartu: Kleio.

Merila-Lattik, Helbe. 2000. Eesti arstid 1940-1960. Tallinn.

Meslé, France and Jacques Vallin. 2003. Mortalité et Causes de Déces en Ukraine au XXe Siecle. Les Cahiers de l'INED, no.152. Paris: Institut National D’Études Démographiques.

Nikander, Timo. 1998. Fertility and Family Surveys in countries of the ECE region. Finland. New York and Geneva: United Nations.

Noack, Turid and Lars Ostby. 1996. Fertility and Family Surveys in countries of the ECE region. Norway. New York and Geneva: United Nations.

Nurk, Õilme (ed). 1999. Küüditatud 1949: Lääne-Virumaa. Rakvere: Memento.

Piir, Enno (ed). 1991-2001. Sakalamaa ei unusta I-XV. Viljandi-Tartu.

PMB. 2004. Rahvastikupoliitika alused. Tallinn: Rahvastikuministri Büroo.

Porket, John. 1979. Old-age Pension Schemes in the Soviet Union and Eastern Europe. Social Policy and Administration 13(1):22-23.

Pullerits, Albert (ed). 1927. Labour and Social Welfare. The Estonian Yearbook 1927. Tallinn, pp. 179-92.

Pullerits, Albert (ed). 1935. Estonia. Population, Cultural and Economic Life. Tallinn: Eesti Raamat.

Puur, Allan. 2000. Change in Economic Status of Older Population: the Case of Estonia during the 1990s. RU Series B, no. 42. Tallinn: EKDK.

Põldma, Asta. 2000. Development of Policies Towards the Elderly in Estonia. Acta Universitatis Carolinae: Geographica, no.1., pp. 93-105. Prague: Charles University.

Rahi, Aigi. 1998. 1949 aasta märtsikü̈̈ditamine Tartu linnas ja maakonnas. Tartu: Kleio.

Raid, K. 1939. Tööstustööliste haiguskindlustus 1937. Eesti Statistika, no. 1, 1k. 28-43. Tallinn: Riigi Statistika Keskbüroo.

Rammul, Aleksander (ed). 1929-1938. Tervishoiuline kirjeldus: Läänemaa, Järvamaa, Viljandimaa, Virumaa, Valgamaa, Võrumaa, Tartumaa, Petserimaa. Tartu.

Riigikantselei. 1935. Valitsusasutiste tegevus 1918-1934. Tallinn: Riigikantselei. 
RKN. 1945. Eesti NSV õigusnormide kogu 1940-1941, vol. III. Tallinn: Eesti NSV Rahvakomissaride Nõukogu Asjadevalitsus.

RSKB. 1923-1925. 1922 aasta üldrahvalugemise andmed, vol. I-III. Tallinn: Riigi Statistika Keskbüroo.

RSKB. 1934-1937. 1934 aasta üldrahvalugemise andmed, vol. I-IV. Tallinn: Riigi Statistika Keskbüroo.

RT. 1920-2002. Riigi Teataja. Tallinn.

Sabbo, Hilda. 1996. Võimatu vaikida, I-III. Tallinn.

Salo, Vello. 1993. Küüditatud 1941. Üldnimestik. Toronto, Maarjamaa.

Schmähl, Winfried and Sabine Horstmann. 2003. Transformation of Pension Systems in Central and Eastern Europe. Cheltenham and Northamptom: Edward Elgar.

Sissas, Hans. 1990-2002. Meenutused. Võru.

SM. 2000. Eesti Tervishoiustatistika 1992-1999. Tallinn: Sotsiaalministeerium.

Teder, K. 1939. Perekonnaseisuametniku käsiraamat. Tallinn: Siseministeerium.

Tellmann, Alvi, Helle Karro ja Viktoria Serkina. 2003. Eesti Meditsiiniline Sünniregister 1992-2002. Eesti Abordiregister 1996-2002. Tallinn: Tervise Arengu Instituut.

Tuisk, Adele. 1931. Pensionid 1925-1930. Eesti Statistika, no. 3, 1k. 161-173.

Tuisk, Adele. 1937. Lastekaitse ja hoolekanne. Eesti Statistika, no. 6, 1k. 277-290.

UNECE. 2000. Fertility and Family Surveys in Countries of the ECE Region. Estonia. New York and Geneva: United Nations.

Vask, A. 1998. Eesti tervishoiusüsteemi arendamine. Tallinn.

Veskimägi, Kaljo-Olev. 1996. Nõukogude unelaadne elu. Tallinn.

Viikberg, Jüri (ed). 1999. Eesti rahvaste raamat. Tallinn: Eesti Entsüklopeediakirjastus. WHO. 2001. Highlights on Health in Estonia. Copenhagen: World Health Organisation. Õispuu, Leo (ed.). 1996-2001. Poliitilised arreteerimised Eestis I-VI. Tallinn: Memento. ÜPT. 1940-1981. Eesti NSV Teataja. Tallinn: Eesti NSV Ülemnõukogu Presiidium. 